\title{
The Effect of Calcium Hydroxideon Mortality of Ascaridia galli In Vitro
}

\author{
Pengaruh Kalsium Hidroksida Terhadap Mortalitas Cacing Ascaridia galli In Vitro \\ ${ }^{1)}$ Inggarsetya Syah Audini, ${ }^{2)}$ Setiawan Koesdarto, ${ }^{3)}$ Ira Sari Yudaniayanti, ${ }^{4)}$ Setyawati Sigit, ${ }^{2)}$ Sri \\ Mumpuni S, ${ }^{2)}$ Agus Sunarso \\ ${ }^{1)}$ Student, ${ }^{2)}$ Department of Parasitology Veteriner, ${ }^{3)}$ Department of Veterinary Clinic, ${ }^{4)}$ Department of \\ Basic Veterinary Medicine. Faculty of Veterinary Medicine, Universitas Airlangga.
}

\begin{abstract}
Ascaridiasis can be happened in either broiler or hens that can caused decrease of meat and egg productions. Ascaridiasis is a parasite that is most often found in poultry and cause high economic losses. This research was conducted to determine the anthelmintic effect of calcium hydroxide $\left[\mathrm{Ca}(\mathrm{OH})_{2}\right]$ on mortality of Ascaridia galli in vitro. In this research used Ascaridia galli with length 7-11 cm without differentiating their sex. The concentrations of calcium hydroxide $\left[\mathrm{Ca}(\mathrm{OH})_{2}\right]$ for immersion the Ascaridia galli were $0,01 \%, 0,02 \%, 0,025 \%$ and $0,03 \%$ as treatment group, respectively. The negative control used aquadest. Observation death A.galli worm and analysis of the data at the 2 hour, 4 hour, 6 hour, 8 hour, 10 hour and 12 hour. The result showed that the increase of concentration increased mortality of Ascaridia galli. Percentage of death worm A.galli at the 12th hour on concentration ,01\%, 0,02\%, 0,025\% and $0,03 \%$ was $20 \%, 55 \%$, $75 \%$ and $100 \%$. ANOVA test showed significant difference between control and treatment group ( $\mathrm{p}<0.05)$. Duncan multiple range test was seen the best treatment was the biggest mortality in concentration of $0,03 \%$.
\end{abstract}

Keywords : Calcium hydroxide, Ascaridia galli, Anthelmintic.

\section{Pendahuluan}

Ascaridiasis merupakan penyakit endoparasit helminth pada peternakan unggas yang disebabkan oleh cacing Ascaridia galli (A. galli). Kasus ascaridiasis tergolong tinggi, terutama pada negara beriklim tropik yang dapat menimbulkan kerugian ekonomi (Beriajaya dkk., 2006). Prevalensi di Asia Tenggara (Indonesia, Malaysia, Thailand, Filipina, Kamboja, Vietnam, Brunei, Laos dan Myanmar)antara 41-92\% (Foster, 2013). Di Indonesia, prevalensi tergolong tinggi yaitu antara 60-90\% (Margono, 2000). Kejadian pada infeksi berat dapat menimbulkan kematian dan kerugian karkas sejumlah 2.240.00o-3.148.0oo ton pertahun (Kusumamiharja, 1992).

Penularan penyakit terjadi secara langsung yaitu dengan tertelannya telur $A$. galli infektif bersama pakan atau minum, dapat juga melalui cacing tanah yang terkontaminasi oleh telur $A$. galli (Subekti dkk., 2013). Anthelmintik yang biasanya digunakan peternak dan dijual di pasaran adalah anthelmintik sintetis yang harganya relatif mahal misalnya adalah piperazin dan albendazole. Adanya masalah tersebut mendorong upaya pencarian anthelmintik yang murah dan mudah dalam mendapatkannya (Hastuti, 2008). Material kalsium hidroksida merupakan zat padat yang berwarna putih dan amorf berasal dari kapur tohor yang mudah didapatkan dengan harga yang murah. Kapur tohor (quick lime) dihasilkan dari batu gamping yang dikalsinasikan (Sukandarrumidi, 1999; Widowati, 2006).

Kalsium hidroksida dapat melepaskan ion $\mathrm{OH}^{-}$yang dapat menginaktifasi enzim dan merusak membran sitoplasma dengan jalan merusak fosfolipid pada membran sitoplasma. Inaktifasi enzim dan rusaknya membran sitoplasma berakibat terganggunya transfer nutrisi dan menyebabkan sel keracunan ion $\mathrm{OH}$ 
(Estrela et al, 1995; Kavitha, 2005). Terhambatnya kerja enzim dapat menyebabkan proses metabolisme pencernaan cacing terganggu sehingga cacing kekurangan tenaga. Membran sitoplasma cacing yang mengalami kerusakan dapat menyebabkan cacing menjadi paralisis dan mati (Tiwow dkk., 2013). Berdasarkan hal tersebut diharapkan kalsium hidroksida $\left[\mathrm{Ca}(\mathrm{OH})_{2}\right]$ mampu membunuh cacing $A$. galli.

Bertitik tolak dari hal tersebut, diperlukan penelitian tentang pengaruh kalsium hidroksida $\left[\mathrm{Ca}(\mathrm{OH})_{2}\right]$ terhadap mortalitas cacing $A$. galli in vitro.

\section{Bahan dan Metode Penelitian}

Penelitian tentang Pengaruh Kalsium Hidroksida Terhadap Mortalitas cacing Ascaridia galli ini telah dilakukan di Laboratorium Helmintologi, Departemen Parasitologi, Fakultas Kedokteran Hewan, Universitas Airlangga, Surabaya. Penelitian berlangsung pada bulan November - Desember 2014. Penelitian ini menggunakan cacing $A$. galli yang memiliki panjang tubuh 7-11 cm, yang diambil dari usus halus ayam yang terinfeksi cacing A. galli di pasar Larangan, Sidoarjo. Bahan yang digunakan pada penelitian ini adalah kalsium hidroksida $\left[\mathrm{Ca}(\mathrm{OH})_{2}\right]$ Merck, $\mathrm{NaCl}$ fisiologis dan aquades.

Cacing A.galli diperoleh dari bagian usus halus ayam. Cacing diambil satu persatu dengan menggunakan pinset anatomis melalui tahapan preparasi. Usus ayam yang diperoleh disayat secara longitudinal sehingga isi usus dapat diamati. Cacing A. galli dewasa yang diperoleh ditampung dan dibersihkan didalam cawan petri yang berisi $\mathrm{NaCl}$ fisiologis. Penelitian ini menggunakan cacing A.galli dewasa berukuran 7 $11 \mathrm{~cm}$ tanpa memperhatikan jenis kelamin. Cacing A. galli yang digunakan sebanyak 10 ekor pada setiap ulangan dalam perlakuan (Putri, 2007;
Mighra, 2007; Moerfiah, Mustabadihardjah dan Winardiana, 2012).

Pembuatan larutan kalsium hidroksida $\left[\mathrm{Ca}(\mathrm{OH})_{2}\right]$ dilakukan dengan cara mencampurkan kalsium hidroksida $\left[\mathrm{Ca}(\mathrm{OH})_{2}\right]$ ditambahkan dengan aquades. Pembuatan larutan kalsium hidroksida dilakukan dengan empat konsentrasi yang berbeda, yaitu larutan kalsium hidroksida konsentrasi $0,01 \%, 0,02 \%, 0,025 \%, 0,03 \%$ dan kontrol (aquades tanpa kalsium hidroksida). Untuk melihat cacing A. galli setelah di inkubasi, apakah mati, paralisis atau masih hidup dilakukan pengusikan pada cacing dengan menggunakan pengaduk kaca. Cacing yang hidup ditandai dengan adanya pergerakan. Jika tidak terdapat pergerakan cacing dipindahkan dalam air panas bersuhu $50^{\circ} \mathrm{C}$. Apabila cacing diam setelah dipindahkan dalam air tersebut, hal ini menunjukkan bahwa cacing mengalami kematian, namun bila terdapat pergerakan pada cacing menandakan bahwa cacing mengalami paralisis (Putri, 2007).

Pada penelitian ini menggunakan Rancangan Acak Lengkap (RAL) (Kusriningrum, 2010). Data yang diperoleh dianalisis dengan uji $\mathrm{F}$ (ANOVA) yang kemudian dilanjutkan dengan uji jarak berganda Duncan untuk menemukan perlakuan mana yang memberikan hasil terbaik dari penelitian ini. Analisis statistik menggunakan Statistical Program Service and Solution (SPSS) for windows 21 (Santoso, 2000).

\section{Hasil dan Pembahasan}

Hasil kumulatif kematian cacing A. galli dapat dilihat pada Tabel 4.1 . Berdasarkan hasil tersebut didapatkan rata-rata persentase kematian cacing $A$. galli pada semua perlakuan dalam waktu pengamatan jam ke-2, ke-4, ke-6, ke-8, ke10 dan ke-12 adalah seperti yang disajikan pada Tabel 1 dan Gambar 1.

Tabel 1. Persentase Kematiazn Cacing Ascaridia galli

\begin{tabular}{|c|c|c|c|c|c|c|}
\hline \multirow{2}{*}{ Perlakuan } & \multicolumn{6}{|c|}{ Waktu Pemeriksaan } \\
\hline & Jam ke-2 & Jam ke-4 & Jam ke-6 & Jam ke-8 & Jam ke-10 & Jam ke-12 \\
\hline Aquades & 0 & o & 0 & o & o & o \\
\hline LKH о,o1\% & o & 2,5 & 7,5 & 12,5 & 17,5 & 20 \\
\hline LKH o, $02 \%$ & o & 7,5 & 17,5 & 30 & 42,5 & 55 \\
\hline LKH o,025\% & 7,5 & 15 & 27,5 & 47,5 & 57,5 & 75 \\
\hline LKH o,o3\% & 15 & 25 & 35 & 65 & 85 & 100 \\
\hline
\end{tabular}

Keterangan LKH o,o1\%: larutan kalsium hidroksida o,o1\%, LKH o,02\%: larutan kalsium hidroksida o,02\%, LKH 0,025\%: larutan kalsium hidroksida 0,025\%, LKH 0,03\%: larutan kalsium hidroksida 0,03\%. 


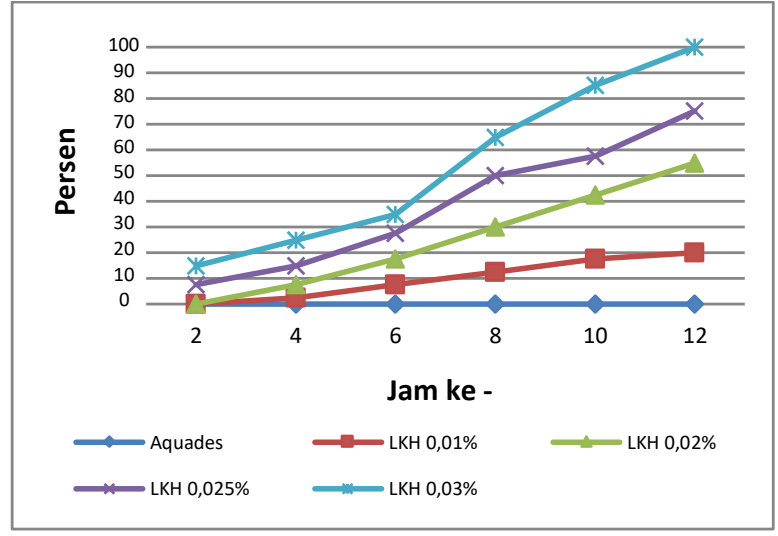

Gambar 1. Grafik mortalitas cacing A. Galli.

Dari data persentase dan grafik yang tercantum dapat diketahui bahwa kematian cacing A. galli pada perlakuan perendaman dengan larutan kalsium hidroksida o,03\% merupakan yang paling banyak dan paling cepat, sedangkan pada perendaman aquades tidak menunjukkan adanya kematian hingga jam ke-12. Analisis statistik dengan Anova serta uji jarak Duncan untuk jam ke-2, jam ke-4, jam ke-6, jam ke-8, jam ke-1o dan jam ke-12 dapat dilihat pada Gambar 1

Hasil pengamatan jam ke-2 dapat diketahui bahwa tidak ada kematian dari cacing A. galli pada perlakuan dengan aquades, larutan kalsium hidroksida $0,01 \%$ dan larutan kalsium hidroksida $\mathbf{0 , 0 2} \%$, namun telah terdapat cacing yang mengalami kematian pada larutan kalsium hidroksida $0,025 \%$ dan pada larutan kalsium hidroksida 0,03\%. Hasil analisis statistik pada pengamatan jam ke-2 menggambarkan tidak adanya perbedaan yang nyata antara perlakuan dengan perendaman aquades, larutan kalsium hidroksida $0,01 \%$ dan larutan kalsium hidroksida 0,02\% namun berbeda nyata pada perlakuan perendaman menggunakan larutan kalsium hidroksida 0,025\% dan larutan kalsium hidroksida 0,03\% yang berarti kedua larutan ini sudah memberikan pengaruh terhadap mortalitas cacing A. galli pada jam ke-2.

Hasil pengamatan pada jam ke-4 menunjukkan telah ada kematian dari cacing $A$. galli baik pada perendaman larutan kalsium hidroksida $0,01 \%$, larutan kalsium hidroksida 0,02\%, larutan kalsium hidroksida 0,025\% dan larutan kalsium hidroksida 0,03\%, sedangkan pada perendaman aquades tidak terdapat kematian cacing $A$. galli. Analisis statistik pada pengamatan jam ke-4 menunjukkan bahwa tidak ada perbedaan yang nyata antara perlakuan dengan perendaman aquades, larutan kalsium hidroksida o,o1\% dan larutan kalsium hidroksida 0,02\% namun berbeda nyata pada perlakuan perendaman menggunakan larutan kalsium hidroksida 0,025\% dan larutan kalsium hidroksida $0,03 \%$ yang berarti larutan kalsium hidroksida o,o1\% dan larutan kalsium hidroksida $0,02 \%$ tidak terlalu memberikan pengaruh pada jam ke-4 karena kedua larutan ini tidak berbeda nyata dengan aquades.

Hasil analisis statistik pada pengamatan jam ke-6, ke-8, ke-10 dan ke-12 menunjukkan bahwa terdapat perbedaan yang nyata antara perlakuan perendaman aquades, larutan kalsium hidroksida 0,01\%, larutan kalsium hidroksida 0,02\%, larutan kalsium hidroksida $0,025 \%$ dan larutan kalsium hidroksida 0,03\%. Hal ini menunjukkan bahwa tiap perlakuan memiliki pengaruh yang berbeda terhadap mortalitas cacing A. galli pada jam ke-6, ke-8, ke-1o dan ke-12.

Persentase kematian cacing A.galli pada jam ke-12 seperti yang disajikan pada Tabel 1, dengan perendaman larutan kalsium hidroksida o,o1\% sebesar $20 \%$, perendaman larutan kalsium hidroksida $0,02 \%$ sebesar $55 \%$, perendaman larutan kalsium hidroksida $0,025 \%$ sebesar $75 \%$ dan perendaman larutan kalsium hidroksida 0,03\% sebesar 100\%. Konsentrasi larutan kalsium hidroksida yang memberikan pengaruh terbaik terhadap mortalitas cacing A. galli adalah larutan kalsium hidroksida $0,03 \%$, hal itu dikarenakan larutan kalsium hidroksida $0,03 \%$ dapat menyebabkan kematian $100 \%$ pada cacing A. galli.

Kalsium hidroksida pada konsentrasi tertentu melepaskan ion $\mathrm{OH}^{-}$yang akan menginaktifasi enzim dan merusak membran sitoplasma. Semua sel hidup baik eukariotik maupun prokariotik memiliki lapisan yang disebut membran sitoplasma yang mengatur keluar masuknya material yang diperlukan. Membran sitoplasma eukariotik dan prokariotik tersusun atas lapisan fosfolipid dan protein. Protein merupakan bagian yang terdapat pada membran sitoplasma yang berfungsi sebagai pembawa yang melayani transfer nutrisi. Kalsium hidroksida dapat menginaktifasi enzim yang ada didalam membran sitoplasma dan merusak 
fosfolipid yang menyebabkan rusaknya membran sitoplasma. Ketika membran sitoplasma rusak, maka berakibat terganggunya transfer nutrisi sehingga sel mengalami keracunan (Estrela et al., 1995; Kavitha., 2005; Lieberman, 2013; Kimball, 2008). Menurut Tiwow dkk, (2013), membran sitoplasma cacing yang rusak dapat menyebabkan cacing paralisis dan terhambatnya kerja enzim dapat menyebabkan proses metabolisme pencernaan cacing terganggu sehingga cacing kekurangan nutrisi yang pada akhirnya cacing akan mati karena kekurangan energi.

Hasil pengamatan terhadap perendaman cacing $A$. galli dengan aquades pada jam ke-2, ke4, ke-6, ke-8, ke1o, dan ke-12 menunjukkan bahwa tidak terdapat cacing $A$. galli yang mati hingga pada jam ke-12.

\section{Kesimpulan}

Berdasarkan hasil penelitian dan rangkaian pembahasan yang telah diuraikan, maka diperoleh kesimpulan bahwa larutan kalsium hidroksida o,o1\%, o,02\%, 0,025\%, dan 0,03\% memiliki pengaruh terhadap mortalitas cacing A. galli dan larutan kalsium hidroksida 0,03\% merupakan konsentrasi yang menyebabkan kematian $100 \%$ pada cacing A. galli pada jam ke-12 secara in vitro.

\section{Daftar Pustaka}

Kusumamihardja, S. 1992. Parasit dan Parasitosis Pada Ternak dan Hewan Piaraan di Indonesia. Pusat Antar Universitas IPB. Bogor. 435 .

Lieberman, M and Allan D.M. 2013. Basic Medical Biochemistry. Lippincolt Williams and Wilkins. Philadelphia. 154.

Margono, S.S. 200o. Nematoda Usus, Dalam Buku: Ganda Usaha. Parasitologi Kedokteran Edisi ke 3. Balai Penerbit FKUI. Jakarta. 9-26.

Mighra, B.A. 2007. Uji Efektifitas Daya Anthelmintik Perasan Buah Segar dan Infus Daun (Ananas comosus L.) Terhadap Ascaridia galli Secara Invitro. Fakultas Kedokteran. Universitas Diponegoro. 9.

Moerfiah, Mustabadihardjah dan Y. Winardiana. 2012. Efektivitas Ekstrak Etanol Biji Labu
Merah (Cucurbita moschata) Sebagai Anthelmintik Terhadap Cacing Ascaridia galli Secara In Vitro Fakultas Matematika dan Ilmu Pengetahuan Alam. Universitas Pakuan. 7.

Putri, DP. 2007. Uji Efektifitas Daya Anthelmintik Carica papaya (Infus Akar, Infus Biji, Infus daun) Terhadap Cacing Ascaridia galli Secara In Vitro [Skripsi]. Fakultas Kedokteran. Universitas Diponegoro. 8.

Santoso, S. 20oo. SPSS Statistik Parametrik. PT. Elex Media Komputindo Kelompok Gramedia. Jakarta.169-173.

Subekti, S. 1990. Khasiat Pemberian Rimpang Temulawak (Curcuma xanthoriza Roxb) Terhadap Ascaridiasis Pada Ternak Ayam. Lembaga Penelitian. Universitas Airlangga, Surabaya.

Subekti, S., S,Koesdarto, Kusnoto, S.M Sosiawati, H. Puspitasari. 2005. Penuntun Praktikum Helmintologi Veteriner. Laboratorium Helmintologi. Bagian Parasitologi. Fakultas Kedokteran Hewan. Universitas Airlangga. Surabaya. 31.

Subekti, S., S.Koesdarto, S.Mumpuni dan Kusnoto. 2013. Buku Teks Helminthiasis Veteriner. Surabaya: Pusat Penerbitan dan Percetakan Universitas Airlangga. 79-82.

Sukandarrumidi, 1999. Bahan Galian Industri. Yogyakarta : Universitas Gadjah Mada Press. 56.

Tiwow, D.W.Bodhi dan N.S.Kojong. 2013. Uji Efek Ekstrak Etanol Biji Pinang (Arecha catechu) Terhadap Cacing Ascaris lumbricoides dan Ascaridia galli secara in vitro. Jurnal Ilmiah Farmasi. UNSRAT Vol.2 No.2. 76.

Widowati, E. 20o6. Pengaruh Lama Perendaman Dengan Larutan Kapur Tohor $\left[\mathrm{Ca}(\mathrm{OH})_{2}\right]$ Pada Kulit Buah Manggis Terhadap Kualitas Kembang Gula Jelly (Skripsi). Fakultas Teknik Universitas Negeri Semarang. 14. 